\title{
Control of Hair Cell Excitability by Vestibular Primary Sensory Neurons
}

\author{
Aurore Brugeaud, ${ }^{1}$ Cécile Travo, ${ }^{1}$ Danielle Demêmes, ${ }^{1}$ Marc Lenoir, ${ }^{1}$ Jordi Llorens, ${ }^{2}$ Jean-Luc Puel,,${ }^{1}$ and \\ Christian Chabbert ${ }^{1}$ \\ ${ }^{1}$ Institut National de la Santé et de la Recherche Médicale Unité 583, 34091 Montpellier, France, and 2Departament de Ciencies Fisiologiques II, Universitat \\ de Barcelona, l'Hospitalet de Llobregat, 08907 Barcelona, Spain
}

In the rat utricle, synaptic contacts between hair cells and the nerve fibers arising from the vestibular primary neurons form during the first week after birth. During that period, the sodium-based excitability that characterizes neonate utricle sensory cells is switched off. To investigate whether the establishment of synaptic contacts was responsible for the modulation of the hair cell excitability, we used an organotypic culture of rat utricle in which the setting of synapses was prevented. Under this condition, the voltage-gated sodium current and the underlying action potentials persisted in a large proportion of nonafferented hair cells. We then studied whether impairment of nerve terminals in the utricle of adult rats may also affect hair cell excitability. We induced selective and transient damages of afferent terminals using glutamate excitotoxicity in vivo. The efficiency of the excitotoxic injury was attested by selective swellings of the terminals and underlying altered vestibular behavior. Under this condition, the sodium-based excitability transiently recovered in hair cells. These results indicate that the modulation of hair cell excitability depends on the state of the afferent terminals. In adult utricle hair cells, this property may be essential to set the conditions required for restoration of the sensory network after damage. This is achieved via re-expression of a biological process that occurs during synaptogenesis.

Key words: voltage-gated sodium channel; hair cells; utricle; excitability; development; excitotoxicity; nerve impairment; repair

\section{Introduction}

The developmental sequence of innervation of vestibular organs has been well described in rodents, based on morphological and functional studies (for review, see Eatock and Hurley, 2003). Nerve fibers arising from Scarpa's ganglion enter the sensory epithelia a few days before birth, and first immature synaptic contacts can already be identified at birth. Synapses acquire their mature phenotype by the end of the first postnatal week (Dechesne et al., 1986; Desmadryl and Sans, 1990), giving rise to the first recordable synaptic activities (Curthoys, 1982; Desmadryl et al., 1986). During that period, hair cells gradually acquire the biophysical properties that bring them their mature character (Rush et al., 1998).

We have previously shown that, at birth [postnatal day 0 (P0) ], rat utricle hair cells transiently express a neuronal-like tetrodotoxin (TTX)-sensitive voltage-gated $\mathrm{Na}^{+}$current $\left(I_{\mathrm{Na}}\right)$, enabling these cells to generate sodium-driven action potentials (APs) (Chabbert et al., 2003). $I_{\mathrm{Na}}$ is downregulated during the

Received July 27, 2006; revised Feb. 15, 2007; accepted Feb. 16, 2007.

This work was supported by the Centre National d'Etudes Spatiales, the French Ministry of Research and New Technologies, and the Spanish Ministry of Education and Science (Grant BFI2003-01606). We thank Drs. G. Desmadryl, G. Geleoc, and W. Marcotti for valuable comments on this work; Drs. S. Bartolami and J. Ruel for helpful discussions; and the Montpellier Regional Center of Cellular Imaging.

Correspondence should be addressed to Dr. Christian Chabbert, Institut National de la Santé et de la Recherche Médicale Unité 583, Institut des Neurosciences de Montpellier, Equipe Physiopathologie et Thérapie de I'Oreille Interne, Groupe d'Etude des Désordres Vestibulaires, Hôpital St. Eloi, 34091 Montpellier cedex 5, France. E-mail: chabbert@univ-montp2.fr.

DOI:10.1523/JNEUROSCI.5185-06.2007

Copyright $\odot 2007$ Society for Neuroscience $\quad$ 0270-6474/07/273503-09\$15.00/0 first postnatal week, decreasing the sodium-based excitability in mature hair cells. This developmental excitability, also observed in the mouse utricle (Geleoc et al., 2004), has also been reported in other sensory organs of the higher vertebrates, such as the cochlea (Evans and Fuchs, 1987; Kros et al., 1998) and the retina (Pan and Hu, 2000; Kawai et al., 2001). Although, in most cases, the physiological relevance of the $I_{\mathrm{Na}}$ remains unknown, we first reported that $I_{\mathrm{Na}}$ was involved in the activity-dependent secretion of brain-derived neurotrophic factor (BDNF) in the neonate rat utricle (Chabbert et al., 2003). Regarding the major role of BDNF in the establishment and the stabilization of synaptic contacts (Ernfors et al., 1995; Schimmang et al., 1995), we proposed that the transient hair cell excitability may contribute to the synaptogenesis process in the vestibular organs. A direct demonstration of this hypothesis remains to be provided.

In this study, we tested the hypothesis that the modulation of hair cell excitability is controlled by the vestibular nerve fibers. We first prevented the establishment of synaptic contacts in neonate rat utricles cultured in vitro before synaptic stabilization. Under this condition, the membrane expression of $I_{\mathrm{Na}}$ and the ability to fire APs persisted in the nonafferented hair cells. We then selectively damaged afferent terminals in adult utricles using glutamate excitotoxicity in vivo. In this condition, a large proportion of hair cells transiently expressed $I_{\mathrm{Na}}$ and recovered the ability to fire APs. These observations demonstrate that the state of the afferent terminals directly affects hair cell excitability. The physiological relevance of this biological process on postinjury repair processes is discussed. 


\section{Materials and Methods}

Animals. Experiments were performed on newborn and adult (40 d old) female Wistar rats in accordance with French Ministry of Agriculture regulations and European Community Council Directive 86/609/EEC, OJL 358, December 18, 1986. Neonate rats were decapitated, and adult animals were anesthetized with a pentobarbital solution injection $(0.1$ $\mathrm{ml} / 100 \mathrm{~g}$ ) before decapitation. All efforts were made to minimize the number of animals used and their suffering.

Denervated utricle organotypic culture. Utricle cultures were prepared as described previously (Gaboyard et al., 2005). Briefly, utricles were explanted aseptically from $\mathrm{P} 0$ rats. The otolith membrane was removed, and utricles were excised. Nerve fibers were trimmed close to the epithelium. Epithelia were embedded in $10 \mu \mathrm{l}$ of extracellular matrix extracted from Engelbreth-Holm-Swarm tumors (Harbor Bio-products, Norwood, MA) on laminin-coated coverslips and covered with $2 \mathrm{ml}$ of feeding medium, a 1:1 mixture of DMEM and Ham's F-12 nutrient (Invitrogen, Gaithersburg, MD) medium supplemented with $10 \%$ fetal bovine serum, glucose $(5 \mathrm{~g} / \mathrm{L})$, glutamine $(1.5 \mathrm{~mm})$, sodium bicarbonate $(1.1$ $\mathrm{g} / \mathrm{L}$ ), and HEPES buffer (15 mM, pH 7.4). Cultures were maintained for $10 \mathrm{~d}$ in a humidified $5 \% \mathrm{CO}_{2}$ atmosphere before electrophysiology and immunocytochemical experiments. The feeding medium was renewed every $3 \mathrm{~d}$.

Excitotoxic impairment of vestibular nerve terminals. Experiments were performed on 78 adult female rats (body weight, 180-250 g). Pharmacological agents were applied to the inner ear as described previously by Guitton et al. (2003). Surgery was performed under general anesthesia induced with isoflurane (Baxter S.A., Lessignes, Belgium), using a Minerve apparatus (induction of $10 \mathrm{~min}$ at $2.5 \%$, maintenance at $2 \%$ under $0.8 \mathrm{~L}$ of $\mathrm{O}_{2} / \mathrm{min}$ ). Under the aseptic condition, the right otic bulla was exposed through a retro-auricular incision, and a hole was created with a micro-drill, revealing the round window. Gelfoam (Gelita Tampon; B. Braun Medical, Melsungen, Germany) filled with $2.5 \mu$ l of artificial perilymph solution (APS) (see below, Electrophysiological recordings), containing $5 \mathrm{~mm}$ kainate, a glutamate receptor agonist (Sigma, St. Louis, $\mathrm{MO}$ ), was applied in the round window niche. The tympanic bulla was closed with dental cement (Unifast Trad; GC Corporation, Tokyo, Japan), and the surgical incision was sutured. We treated 42 rats with kainate alone ( 17 for electron microscopy, 12 for immunochemistry, and 13 for electrophysical investigations) and 15 rats with kainate plus 200 $\mu \mathrm{M}$ 6,7-dinitroquinoxaline-2,3(1H,4H)-dione (DNQX; Sigma), a competitive kainate/quisqualate (non-NMDA) receptor antagonist (6 for electron microscopy, 6 for immunochemistry, and 3 for electrophysiology). Twenty-one animals were used as control with gelfoam filled with $2.5 \mu \mathrm{l}$ of APS alone. After surgery, animals were returned to their cages and maintained at $22 \pm 2^{\circ} \mathrm{C}$.

Thin sections and transmission electron microscopy. Utricles were processed as reported previously (Seoane et al., 2001). Briefly, sensory epithelia were rapidly removed and fixed by incubation for $2 \mathrm{~h}$ in $1 \%$ paraformaldehyde and $2.5 \%$ glutaraldehyde in $0.1 \mathrm{~m}$ PBS. They were then kept overnight in $0.1 \mathrm{~m} \mathrm{PBS}$ at $4^{\circ} \mathrm{C}$. Classical techniques were used to prepare the samples for transmission electron microscopy: postfixation for $1 \mathrm{~h}$ in $1 \% \mathrm{OsO}_{4}$ in cacodylate buffer, $\mathrm{pH} 7.2$, subsequent dehydration with increasing concentrations of ethanol $\left(70,95\right.$, and $\left.100^{\circ}\right)$, and embedding in epoxy resin. Utricles were longitudinally sectioned in $1 \mu \mathrm{m} \mathrm{sec}-$ tions with a diamond knife on an ultramicrotome (Reichert OMU3, Vienna, Austria). Sections were stained with toluidine blue (Rhône Poulenc, Villers St. Paul, France). Ultrathin transverse sections were cut, stained with $2 \%$ uranyl acetate and lead citrate, and examined using a Jeol (Tokyo, Japan) 6300F electron microscope.

Morphological evaluation of nerve terminal damages. The degree of nerve terminal swelling was estimated by measuring the thickness of the calyces at half their height (corresponding to the level of the type I hair cell nucleus) and the diameter of the boutons innervating the type II hair cells under each experimental condition using Metamorph software (Universal Imaging Corporation, West Chester, PA). Swelling was measured from semithin sections of three utricles for each experimental condition. The proportion of nerve terminals damaged by the kainate treatment in each epithelium was estimated on entire semithin sections cut through the longitudinal axis of treated $(n=5)$ and control $(n=5)$ utricles. Nerve terminals displaying widths larger than $1 \mu \mathrm{m}$ were considered as swollen. We counted the total number of hair cells present in each semithin section and determined the percentage of hair cells that displayed swollen terminals. The evaluation was made on single sections chosen randomly over series of consecutive sections of each utricle to mimic the conditions encountered in the electrophysiological recordings. Student's $t$ test $(p<0.05)$ was used to characterize the significant relevance.

Evaluation of vestibular dysfunction. Vestibular dysfunction was evaluated by observation of spontaneous motor behavior as described previously (Boadas-Vaello et al., 2005). Briefly, rats were placed for $1 \mathrm{~min}$ on a table top, and the experimenter rated the animals from 0 to 4 for circling, retropulsion, and abnormal head movements. Circling was defined as stereotyped circling movement. Retropulsion consisted of backward displacement of the animal. The head bobbing consisted of intermittent extreme backward extension of the neck. The rats were also rated $0-4$ for the tail-hang reflex, contact inhibition of the righting reflex, and air-righting reflex tests. When lifted by the tail, normal rats exhibit a "landing" response consisting of forelimb extension. Rats with impaired vestibular function bent ventrally, sometimes "crawling" up toward their tails, thus tending to occipital landing. For the contact inhibition of the righting reflex, rats were placed supine on a horizontal surface, and a metal bar grid was lightly placed in contact with the soles of the animals' feet. Healthy rats quickly right themselves, whereas the vestibulardeficient rats lie on their back, with their feet up, and "walk" with respect to the ventral surface. For the air-righting reflex, the animals were held supine and dropped from a height of $40 \mathrm{~cm}$ onto a foam cushion. Normal rats are successful in righting themselves in the air, whereas vestibulardeficient rats are not. The results of all tests were combined and expressed as a percentage (vs a maximal score of 24). To provide a positive control condition for the behavioral assessment of vestibular dysfunction, four animals were injected intraperitoneally with $1000 \mathrm{mg} / \mathrm{kg} \operatorname{IDPN}\left(3,3^{\prime}-\right.$ iminodipropionitrile) $2 \mathrm{~d}$ before behavioral assessment. This treatment causes a complete loss of vestibular hair cells and hence of vestibular function (Llorens et al., 1993).

Electrophysiological recordings. Whole-cell voltage- and current-clamp recordings were made using an Axopatch 200B amplifier (Molecular Devices, Sunnyvale, CA) in hair cells from cultured or acutely isolated rat utricles as described previously (Chabbert et al., 2003). Epithelia were placed in an experimental chamber containing $2 \mathrm{ml}$ of APS (in mM: 137 $\mathrm{NaCl}, 0.7 \mathrm{NaH}_{2} \mathrm{PO}_{4}, 5.8 \mathrm{KCl}, 1.3 \mathrm{CaCl}_{2}, 0.9 \mathrm{MgCl}_{2}, 5.6 \mathrm{D}$-glucose, and 10 HEPES-NaOH, pH 7.4, adjusted to $305 \mathrm{mOsm} / \mathrm{L}$ ). Amino acids and vitamins for Eagle's MEM were added from concentrates (Invitrogen). The pipette solution contained the following (in $\mathrm{mm}$ ): $135 \mathrm{KCl}, 0.1$ $\mathrm{CaCl}_{2}$, 5 EGTA, $3 \mathrm{MgATP}, 1 \mathrm{NaGTP}$, and 5 HEPES-NaOH, pH 7.3, adjusted to $300 \mathrm{mOsm} / \mathrm{L}$. After seal formation (>10 G $\Omega$ ) onto the basolateral membrane of hair cells and membrane disruption, the membrane capacitance $\left(C_{\mathrm{m}}, 5.4 \pm 1.4 \mathrm{pF} ; n=16\right)$ and series resistance $\left(R_{\mathrm{s}}, 4-10\right.$ $\mathrm{M} \Omega$ ) were estimated from the decay of the capacitive transient induced by a $\pm 10 \mathrm{mV}$ pulse from a holding potential of $-100 \mathrm{mV}$. $R_{\mathrm{s}}$ was compensated for up to $85 \%$ after cancellation of the capacitive transients. Voltage errors resulting from uncompensated $R_{\mathrm{s}}$ did not exceed $5 \mathrm{mV}$ and were not corrected. No linear leakage compensation was performed, and the liquid junction potential was not corrected $(-2 \mathrm{mV})$. Data were collected using pClamp 9.0 software (Molecular Devices) and analyzed with Origin 4.1 software (Microcal Software, Northampton, MA). Data were sampled at 5 or $10 \mathrm{kHz}$ and filtered at a half-sampling rate (eightpole Bessel filter). The mean chord conductances of $I_{\mathrm{Na}}$ were calculated from the currents adjusted for driving force, assuming a $\mathrm{Na}^{+}$reversal potential of $+56 \mathrm{mV}$. This value was estimated by applying $1 \mathrm{~ms}$ voltage steps to $-30 \mathrm{mV}$ from a holding potential of $-110 \mathrm{mV}$ to fully activate $I_{\mathrm{Na}}$, followed by $20 \mathrm{~ms}$ depolarizations from -80 to $+70 \mathrm{mV}$ in $10 \mathrm{mV}$ increments. Protocols for voltage activation and inactivation of $I_{\mathrm{Na}}$ and current injections are described in the legend to Figure 1. Relative activation curves for $I_{\mathrm{Na}}$ were best fitted with a single Boltzmann function of the following form: $G_{\mathrm{Na}} / G_{\mathrm{Na} \text {, } \max }=1 /\left(1+\exp \left(V_{1 / 2}-V_{\mathrm{m}}\right) / k\right.$ for activation, where $G_{\mathrm{Na}}$ is the voltage-dependent sodium conductance, $G_{\mathrm{Na} \text {, max }}$ is the maximal sodium conductance, $V_{1 / 2}$ is the potential at which acti- 
vation is half-maximal, $V_{\mathrm{m}}$ is the membrane potential, and $k$ is the slope factor. Relative inactivation curves of $I_{\mathrm{Na}}$ were fitted using the following equation: $I_{\mathrm{Na}} / I_{\mathrm{Na} \text {, } \max }=1 /\left(1+\exp \left(V_{\mathrm{m}}-V_{1 / 2}\right) / k\right.$, where $I_{\mathrm{Na} \text {, max }}$ is the peak sodium current elicited after the more hyperpolarized prepulse, $V_{\mathrm{m}}$ is the preconditioning pulse potential, and $V_{1 / 2}$ is the half-inactivation potential.

We checked for the presence of $g_{\mathrm{K}, \mathrm{L}}$, a negative activating delayed rectifier current that distinguishes between type I and type II hair cells, using a protocol described in detail previously (Gaboyard et al., 2005). Hair cells displaying $I_{\mathrm{Na}}$ with a half-inactivation more hyperpolarized than $-85 \mathrm{mV}$, characteristic of the TTX-insensitive sodium current, carried by the $\mathrm{Na}_{\mathrm{v}} 1.5$ subunit, and mostly found in the striolar region of the rat utricle (Wooltorton et al., 2005) were excluded from the analysis. The chamber was continuously superfused at a rate of $1 \mathrm{ml} / \mathrm{min}$, using a peristaltic pump. All experiments were conducted at room temperature $\left(22-24^{\circ} \mathrm{C}\right)$. Results are presented as mean \pm SD. $n$ values represents the total number of hair cells studied in each experimental condition.

Immunocytochemistry. Utricles were fixed by incubation overnight at $4^{\circ} \mathrm{C}$ with $4 \%$ paraformaldehyde in $0.1 \mathrm{M}$ PBS, pH 7.4. They were embedded in $4 \%$ agarose (Invitrogen, Palsley, UK) in PBS and cut into $60 \mu \mathrm{m}$ sections with a vibrating blade microtome in ice-cold PBS. Free-floating sections were incubated for $1 \mathrm{~h}$ at $4^{\circ} \mathrm{C}$ in PBS supplemented with $10 \%$ normal donkey serum and $0.3 \%$ Triton X-100. The sections were incubated overnight at $4^{\circ} \mathrm{C}$ with a rabbit polyclonal antibody recognizing the $\alpha$-subunit of the voltage-gated sodium channel $\left(\mathrm{Na}_{\mathrm{v}} 1.2\right)$ (brain type II, 1:100; Sigma), together with a mouse monoclonal anti-neurofilament 200 antibody (clone N52, 1:500; Sigma), in PBS supplemented with 5\% normal donkey serum and $0.1 \%$ Triton X-100. Sample sections were rinsed with PBS, incubated for $2 \mathrm{~h}$ at room temperature with biotinylated anti-rabbit IgGs (1:300; Jackson ImmunoResearch, West Grove, PA), and incubated with streptavidin Alexa-Fluor 546 conjugate (1:500; Invitrogen) and fluorescein isothiocyanate-conjugated anti-mouse IgGs (1:300; Jackson ImmunoResearch). Sections were mounted in Fluorsave Reagent (Calbiochem, Meudon, France) and observed with a Bio-Rad (Hercules, CA) MRC 1024 laser-scanning confocal microscope equipped with $40 \times$ and $63 \times$ oil-immersion lenses. For all ages of rat studied, negative controls, for which the primary antibody was omitted, showed no specific fluorescence (data not shown).

Statistical tests. Statistical analyses were performed using the $\chi^{2}$ test (significant at least $p<0.05)$ for the percentage of $I_{\mathrm{Na}}$ expression and Student's $t$ test $(p<0.05)$ to compare $I_{\mathrm{Na}}$ densities. ANOVA $(p<0.05)$, followed by Duncan's test $(p<0.05)$, was used for behavioral scores. Statistically significant differences are indicated by asterisks $\left(^{*}\right)$ in the figures.

\section{Results}

Persistence of electrical excitability in nonafferented utricle hair cells

At birth in the rat utricle, most hair cells $(78.9 \%$, 45 of 57$)$ transiently express a voltage-gated sodium current $\left(I_{\mathrm{Na}}\right)$ that brings them the ability to fire sodium-based APs (Chabbert et al., 2003). During the first postnatal week, $I_{\mathrm{Na}}$ is dramatically downregulated and remains in a small population of hair cells from P10 until adulthood (Fig. 1A). Because the first postnatal week is a period of intense synaptogenesis in the rodent vestibular organs (Curthoys, 1982; Desmadryl et al., 1986), we hypothesized that the downregulation of $I_{\mathrm{Na}}$ in hair cells resulted from the establishment of synaptic contacts with the nerve fibers arising from the vestibular ganglion. To test this hypothesis, we checked whether preventing the setting of synaptic contacts may affect the developmental expression of $I_{\mathrm{Na}}$ in hair cells. Utricles were acutely excised at P0 and maintained in culture for $10 \mathrm{~d}$ $(\mathrm{P} 0+10 \mathrm{DIV})$ without vestibular ganglion. In this condition, whole-cell patch-clamp recordings revealed that a large percentage of P0+10DIV hair cells still expressed $I_{\mathrm{Na}}(64.0 \%, 16$ of 25$)$ (Fig. $1 A$ ), contrary to those after $10 \mathrm{~d}$ of normal development, P10 (9.6\%, 3 of 31$)$. At P0+10DIV, both hair cell types could be

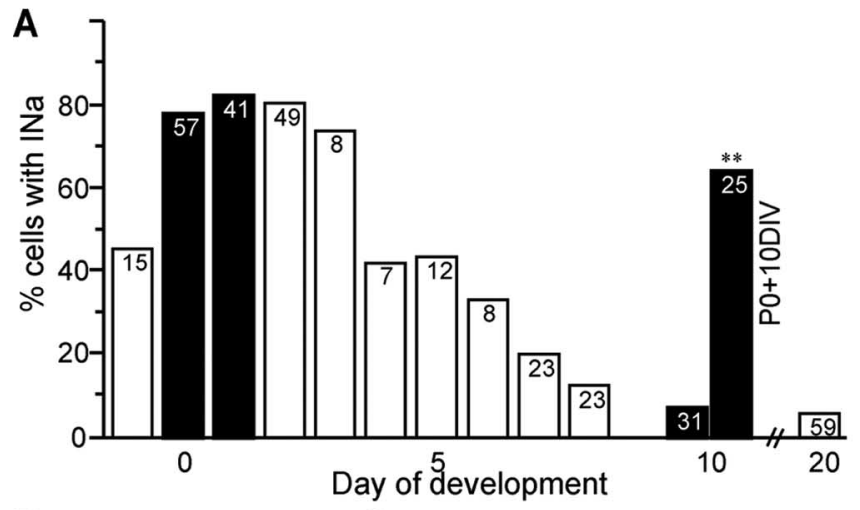

B C
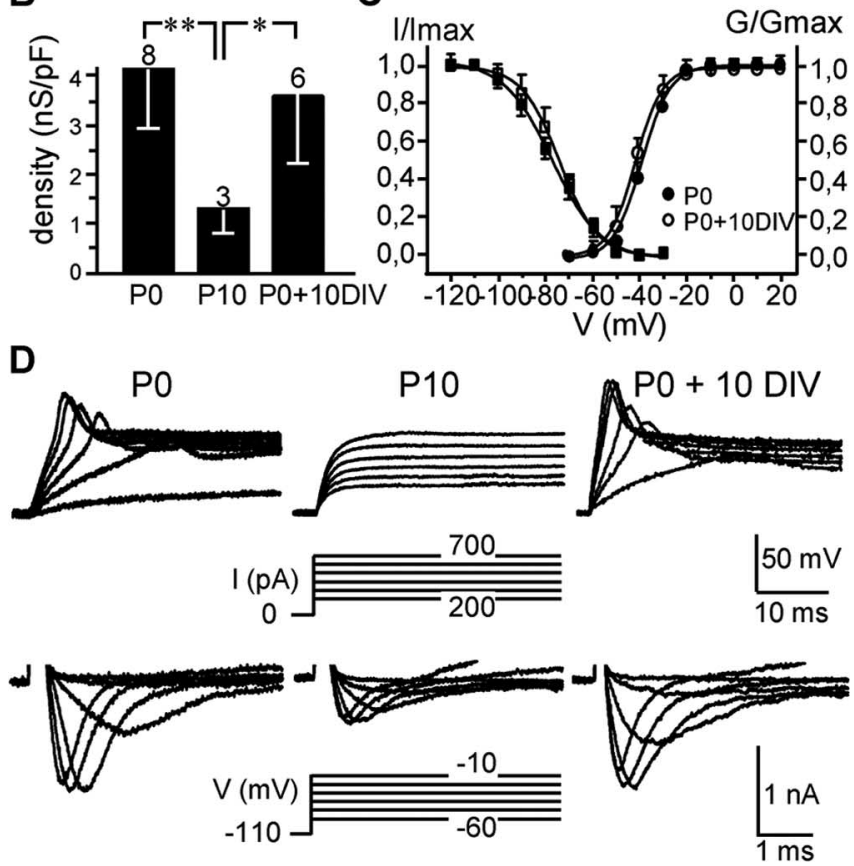

Figure 1. Persistence of electrical excitability in nonafferented utricle hair cells in culture. $\boldsymbol{A}$, Diagram showing the percentage of utricle hair cells expressing $/_{\mathrm{Na}}$ as a function of rat age. Data in open bars were taken from Chabbert et al. (2003). Data in filled bars were recorded in hair cells from utricle acutely isolated at P0, P1, and P10 and from cultured utricle (P0+10DIV) $\left({ }^{* *} p<0.01\right) \cdot \boldsymbol{B}$, Comparison of $/$ Na density (mean $\pm S D$ ) at indicated stages $\left({ }^{*} p<0.05,{ }^{* *} p<\right.$ 0.01). Mean membrane capacitances $\left(C_{\mathrm{m}}\right)$ did not differ significantly between stages: $4.3 \pm 1.4$ $\mathrm{pF}$ at P0, 3.7 $\pm 0.9 \mathrm{pF}$ at P10, and $4.0 \pm 1.1 \mathrm{pF}$ at P0+10DIV. In $\boldsymbol{A}$ and $\boldsymbol{B}$, the total number of cells studied at each stage of development is shown at the top of each bar. $\boldsymbol{C}$, Plot of relative activation ( ; between -70 and $+20 \mathrm{mV}$ from a $V_{\text {hold }}$ of $-110 \mathrm{mV}$ ) and inactivation ( $\square$; test potentials, $5 \mathrm{~ms}$ at $-30 \mathrm{mV}$; conditioning prepulses, $10 \mathrm{~ms}$ between -120 and $-30 \mathrm{mV}$ from a $V_{\text {hold }}$ of $-110 \mathrm{mV}$ ) of $I_{\mathrm{Na}}$ at indicated stages, expressed as $G / G_{\max }$ and $I / I_{\max }$ as a function of test potentials and conditioning prepulses, respectively. $\boldsymbol{D}$, Representative voltage responses (top traces) in the current-clamp mode of the whole-cell patch-clamp technique, following a given protocol and at indicated stages of development. Underlying whole-cell currents recorded in voltage-clamp mode are given below. Capacitive transients have been truncated for clarity. Depolarizing current injections (100 pA steps) were applied to cells held under a hyperpolarizing holding current. Traces shown in the figure are single traces.

distinguished ( $40 \%$ type I, $60 \%$ type II; $n=20$ ) based on the presence of the low-voltage activating outwardly rectifying conductance $\left(g_{\mathrm{K}, \mathrm{L}}\right)$ (Correia and Lang, 1990; Chen and Eatock, $2000) . I_{\mathrm{Na}}$ was present in half of the type I hair cells ( 4 of 8 ) and in two-thirds of the type II hair cells (8 of 12). The density of $I_{\mathrm{Na}}$ obtained by dividing the maximal sodium conductance $\left(G_{\mathrm{Na} \text { max }}\right)$ by the hair cell membrane capacitance did not differ between hair cells after $10 \mathrm{~d}$ in culture $(3.6 \pm 1.4 \mathrm{nS} / \mathrm{pF} ; n=6)$ and $\mathrm{P} 0$ hair cells 
$(4.1 \pm 1.2 \mathrm{nS} / \mathrm{pF} ; n=8)$ but was significantly higher $(p<0.05)$ than those of P10 hair cells $(1.3 \pm 0.5 \mathrm{nS} / \mathrm{pF} ; n=3)$ (Fig. $1 B)$. The pharmacological properties (complete block by 100 nM TTX; data not shown) and biophysical properties of $I_{\mathrm{Na}}$ in P0+10DIV hair cells did not differ from those of P0 hair cells (Fig. 1C, Table 1). Figure $1 D$ (bottom) shows representative $I_{\mathrm{Na}}$ in $\mathrm{P} 0, \mathrm{P} 10$, and $\mathrm{P} 0+10 \mathrm{DIV}$ hair cells, respectively. Similar to what is observed at P0, TTX-sensitive APs could be evoked in hair cells at P0+10DIV by the injection of depolarizing currents in the range of those that would be carried by mechanosensitive transduction channels (Fig. 1D). No such APs were elicited in acutely excised P10 hair cells. Together, these observations reveal that the downregulation of $I_{\mathrm{Na}}$ in the utricle hair cells does not occur in absence of ongoing innervation.

\section{Recovery of excitability in hair cells after nerve terminal impairment}

To examine whether a similar property may explain the lack of excitability in adult hair cells, we investigated whether impairment of afferent nerve terminals in adult utricles (subsequently to synapse stabilization) led to the recovery of hair cell excitability. Initially, we aimed to record $I_{\mathrm{Na}}$ in utricles explanted from adult rats and maintained for several days in culture. The nerve terminals present in the epithelia degenerated in $1 \mathrm{~d}$. Unfortunately, we could not achieve satisfactory culture conditions for recording hair cell currents. We overcame this problem by inducing selective damage of nerve terminals in vivo, in adult rats. We adapted to the rat vestibule, a method previously developed in the mammalian cochlea to induce transient excitotoxic injuries to the first auditory synapse (Puel et al., 1994; Guitton et al., 2003). We applied a gelfoam containing $5 \mathrm{~mm}$ kainate into the round window niche of adult P40 rats. Indeed, kainate has been shown to induce excitotoxic damages to vestibular synapses (Liu, 1999). Figure 2 illustrates the consequences of kainate treatment on the nerve terminals in utricles. Swellings of calyx and bouton nerve terminals were clearly identifiable on the entire utricle $48 \mathrm{~h}$ after kainate application (Fig. 2A, K+48h). These swellings were particularly marked in the striolar region, in which type I hair cells were often expulsed from their calyx anchorage. Swellings were less pronounced in the peristriolar region, but both calyx and bouton nerve terminals were destructured with respect to those present in control ears (Figs. $2 B, C, 3 A-D$ ). Quantitative assessment revealed that the population of hair cells displaying swollen afferent terminals in treated utricles $(75.1 \pm 5.82 \%$; 540 of 728 cells studied over five epithelia) was significantly higher $(p<0.001)$ than those observed in control condition (5.8 $\pm 2.7 \%$; 59 of 1015 cells over five epithelia) (Fig. 2D). In our experimental conditions, kainate-induced impairments were transient. No morphological trace of swelling was observed 1 week after kainate application $(n=3)$ (Fig. $3 E, F)$. The specificity of the excitotoxic injury was confirmed by the absence of morphological damage when DNQX $(n=3)$, a competitive non-NMDA receptor antagonist, was applied simultaneously with kainate (Fig. $3 G, H$ ). Estimation of the nerve terminal size in each condition is given in Table 2. Morphological examination of the synapses structure at higher-
Table 1. Electrophysiological properties of $I_{\mathrm{Na}}$

\begin{tabular}{lll}
\hline Conditions & $V_{1 / 2}$ act $(\mathrm{mV})$ & $V_{1 / 2}$ inact $(\mathrm{mV})$ \\
\hline P0 & $-40.1 \pm 2.3(10)$ & $-77.6 \pm 2.9(6)$ \\
P0 +10DIV & $-43.1 \pm 4.0(6)$ & $-74.1 \pm 4.8(4)$ \\
K+48h & $-43.4 \pm 6.6(10)$ & $-72.6 \pm 4.6(3)$ \\
\hline
\end{tabular}

Mean potentials at which half of the sodium channels of the cell are activated $\left(V_{1 / 2}\right.$ act $)$ or inactivated $\left(V_{1 / 2}\right.$ inact $)$ in given experimental conditions are shown. No significant difference in $V_{1 / 2}$ act and $V_{1 / 2}$ inact was observed between the studied conditions. Data are given as mean \pm SD, and the total number of cells studied is given in parentheses.
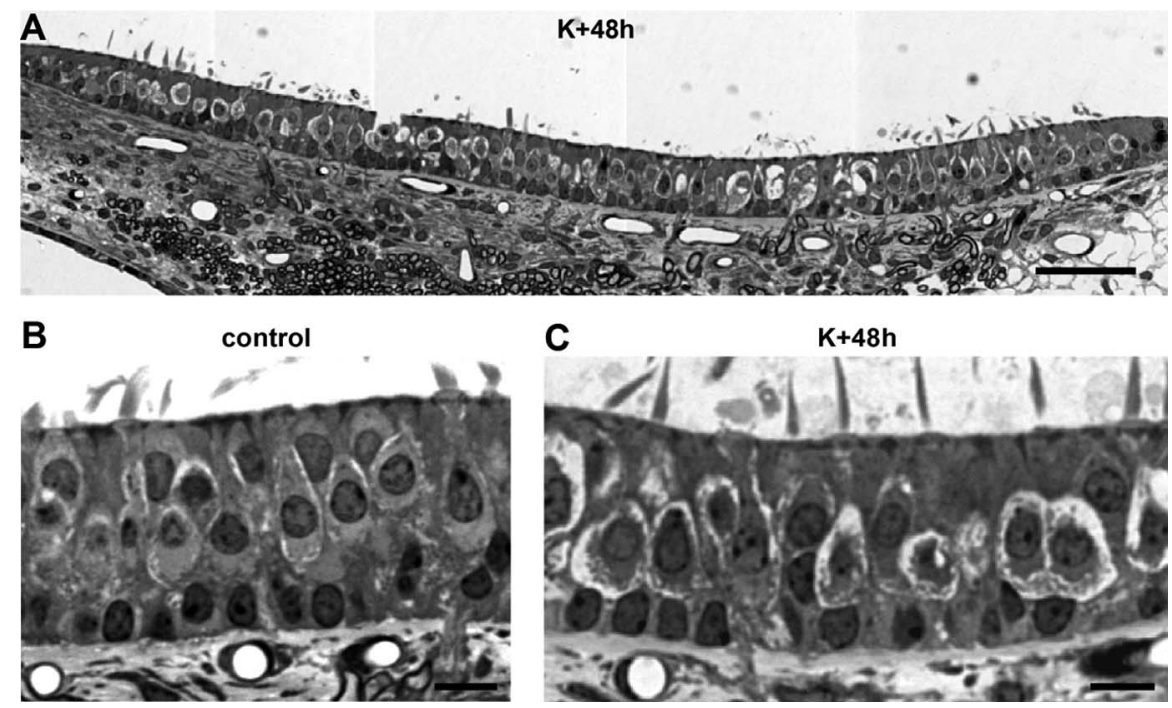

Figure 2. Morphological evaluation of excitotoxic damages. $\boldsymbol{A}$, Longitudinal sections through the entire utricle revealing numerous swollen nerve terminals below hair cells at $\mathrm{K}+48 \mathrm{~h}$. $\boldsymbol{B}, \boldsymbol{C}$, High-magnification observations in control and $\mathrm{K}+48 \mathrm{~h}$ conditions. Scale bars: $\boldsymbol{A}, 30 \mu \mathrm{m} ; \boldsymbol{B}, \boldsymbol{C}, 10 \mu \mathrm{m}$.

magnification did not reveal significant alteration of the active zone organization both in hair cells and in afferent nerve terminals (Fig. 4). Ribbons were always found at the contact with the basal hair cell membrane and surrounded by numerous synaptic vesicles as reported in control preparations. Postsynaptic densifications were also identifiable at the afferent terminals membrane facing the ribbons, although disorganization of their internal ultrastructure was clearly identifiable in the $\mathrm{K}+48 \mathrm{~h}$ condition. Efferent terminals never displayed any sign of swelling (Fig. $4 I-K)$.

Consequences of the afferent terminal impairment on the vestibular function were evaluated using a battery of tests that included observation of spontaneous motor behavior described previously (Boadas-Vaello et al., 2005). Rats treated with kainate transiently displayed signs of vestibular dysfunction. This was attested by a significant increase in the rating scores of vestibular dysfunction at $\mathrm{K}+48 \mathrm{~h}$ relative to control rats. Signs of vestibular dysfunction were no longer detected 1 week after kainate application or under neuroprotection conditions (Fig. 5).

During afferent terminal impairment $(\mathrm{K}+48 \mathrm{~h})$, the proportion of utricle hair cells expressing $I_{\mathrm{Na}}$ increased dramatically with respect to control hair cells still afferented at P40 (55.2\%, 16 of 29 vs $5.8 \%, 1$ of $17 ; p<0.01$ ) (Fig. $6 A$ ). Forty percent of the tested cells ( 6 of 15$)$ were identified as type I hair cells. $I_{\mathrm{Na}}$ was present in one-third (2 of 6) of these latter cells. The density of $I_{\mathrm{Na}}$ in hair cells at $\mathrm{K}+48 \mathrm{~h}$ was in the same order to that estimated in $\mathrm{P} 0$ cells $(3.1 \pm 0.1 \mathrm{nS} / \mathrm{pF}, n=4$, vs $4.1 \pm 1.2 \mathrm{nS} / \mathrm{pF}, n=8)$. The pharma- 

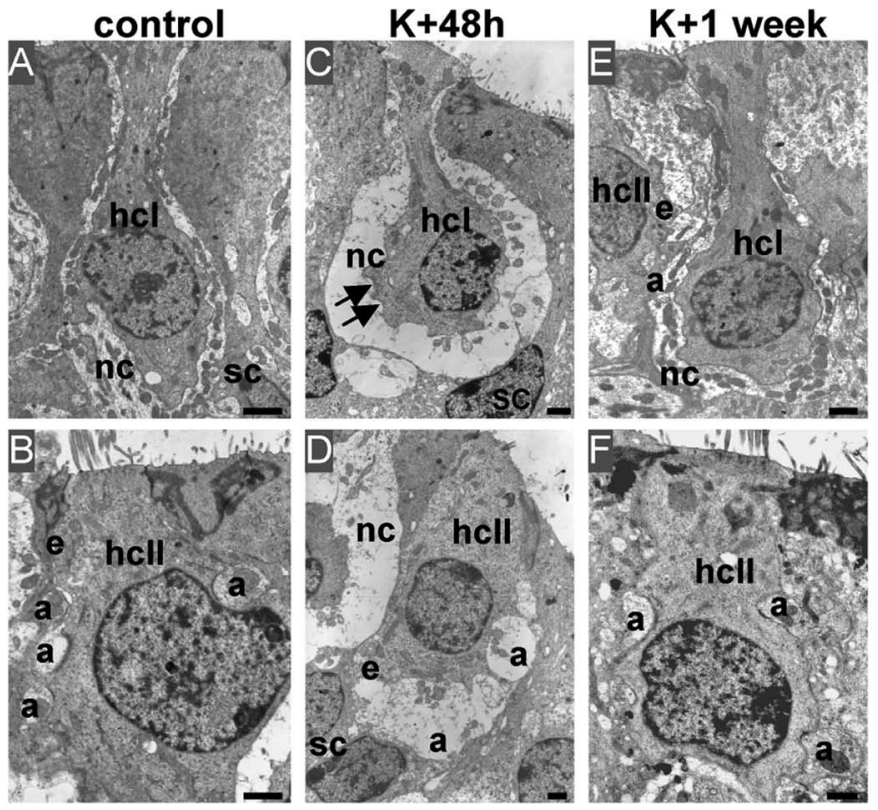

Figure 3. Morphological consequences of transient nerve terminal impairment. Electron microscopy observations of vestibula nerve terminals at type I (hcl; top) and type II ( $h$ cll; bottom) hair cells in the peristriolar region of utricles from adult rats in given conditions are shown. $\boldsymbol{A}, \boldsymbol{B}$, lllustration of intact nerve calyx, afferent, and efferent bouton terminals in control utricles. $\boldsymbol{C}, \boldsymbol{D}$, Forty-eight hours after kainate application, both calyx and bouton terminals displayed characteristic swellings. The calyx membrane often came off from the hair cell membrane (arrows). Bouton swellings resulted in indentations of type II hair cell basal membrane. $\boldsymbol{E}-\boldsymbol{H}$, No damage persisted in the sensory epithelium 1 week after kainate application $(\boldsymbol{E}, \boldsymbol{F})$ or if DNQX was applied with kainate $(\boldsymbol{G}, \boldsymbol{H})$. nc, Nerve calyx; a, afferent; e, efferent; sc, supporting cells. Scale bars, $1 \mu \mathrm{m}$.

Table 2. Size analysis of nerve terminals

\begin{tabular}{lll}
\hline Conditions & Calyces $(\mu \mathrm{m})$ & Boutons $(\mu \mathrm{m})$ \\
\hline Control & $0.61 \pm 0.03(49)$ & $0.84 \pm 0.03(36)$ \\
K $+48 \mathrm{~h}$ & $2.09 \pm 0.14(39)$ & $2.32 \pm 0.26(25)$ \\
K +1 week & $0.65 \pm 0.02(12)$ & $0.75 \pm 0.03(32)$ \\
K+DNQX+48h & $0.54 \pm 0.02(23)$ & $0.86 \pm 0.10(11)$ \\
\hline
\end{tabular}

Sizes of calyx and bouton terminals measured in given experimental conditions are shown. Nerve terminal size is significantly larger in the $\mathrm{K}+48 \mathrm{~h}$ condition relative to other given conditions $(p<0.001)$. Values are given as mean $\pm S D$ in each condition, and the total number of cells studied is given in parentheses.

cological (data not shown) and biophysical properties of $I_{\mathrm{Na}}$ in hair cells at $\mathrm{K}+48 \mathrm{~h}$ did not differ significantly from those of hair cells in utricles acutely isolated at P0 (Table 1). Hair cells displaying $I_{\mathrm{Na}}$ density $\geq 3 \mathrm{nS} / \mathrm{pF}$ displayed TTX-sensitive APs on injection of depolarizing currents (Fig. 6B). One week after kainate application, hair cells were no longer able to express high $I_{\mathrm{Na}}$ density and to generate sodium-based APs $(n=11)$. These properties were also not observed if DNQX was applied simultaneously with kainate $(n=14)$.

We previously reported that $\mathrm{Na}_{\mathrm{v}} 1.2$, one of the commonest voltage-gated sodium channel $\alpha$-subunits in rat utricle hair cells, is downregulated during synaptogenesis (Chabbert et al., 2003). To study whether the regulation of $\mathrm{Na}_{\mathrm{v}} 1.2$ expression during synaptic impairment may support the observed re-expression of $I_{\mathrm{Na}}$, we checked its membrane expression using immunochemistry. $\mathrm{Na}_{\mathrm{v}} 1.2$ was not detected in utricle hair cells from adult control rats (Fig. 7A). However, $48 \mathrm{~h}$ after kainate application, $\mathrm{Na}_{\mathrm{v}} 1.2$ immunostaining dramatically increased in hair cells. The labeling was prominent at the hair cell basal membrane (Fig. 7B). Recovery of $\mathrm{Na}_{\mathrm{v}} 1.2$ staining did not persist beyond 1 week after kainate treatment in most studied utricles (four of five) (Fig. 7C). $\mathrm{Na}_{\mathrm{v}} 1.2$ membrane re-expression was not observed when DNQX was ap-
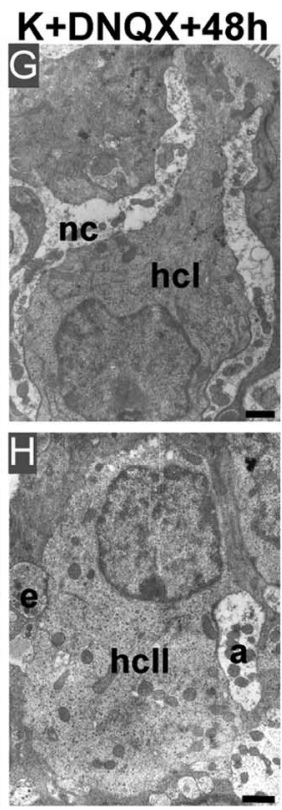

plied with kainate (all three rats tested) (Fig. 7D). These observations reveal that impairment of the afferent terminals in adult rat utricle triggers the re-expression of $\mathrm{Na}_{\mathrm{v}} 1.2$ at the hair cell membrane.

\section{Discussion}

This study shows that the modulation of the sodium-based excitability of the sensory cells is dependent on the state of the afferent terminals in the mammal utricle. The voltage-gated sodium current expression and underlying hair cell excitability are downregulated in neonate utricles as the ongoing nerve fibers contact the hair cells. Conversely, when mature afferent terminals are selectively impaired in vivo, hair cells re-express $I_{\mathrm{Na}}$ and recover the ability to fire sodium-based APs. These observations provide new data that help to understand the cellular interactions involved in synaptogenesis and postinjury repair of the vestibular sensory organs.

\section{Persistence of electrical excitability in nonafferented utricle hair cells}

Denervated organotypic culture has been used previously to test whether morphological or electrophysiological differentiation depended on ongoing innervation (Rusch et al., 1998). Results obtained on mouse utricles demonstrated that neither calyx formation nor sustained postnatal innervation was required for morphological differentiation of the two types of hair cells, nor for the developmental acquisition of voltage-gated potassium currents. Using a similar preparation in the rat, we confirmed that the developmental expression of $g_{\mathrm{K}, \mathrm{L}}$ is independent on innervation (Gaboyard et al., 2005). Conversely, the present study shows that the developmental expression of $I_{\mathrm{Na}}$ depends on the ongoing innervation, because the downregulation of voltage-gated sodium currents does not occur in the absence of synaptogenesis. This applies to both hair cell types. At $\mathrm{P} 0+10 \mathrm{DIV}$, the density of $I_{\mathrm{Na}}$ in hair cells remained relatively high, allowing hair cells to fire sodium-based APs as in the neonate period. This could be interpreted as a consequence of a bloc of hair cell differentiation under the culture conditions, because the large density of $I_{\mathrm{Na}}$ is usually restricted to $\mathrm{P} 0-\mathrm{P} 3$ hair cells in the rat utricle (Chabbert et al., 2003). However, because other voltage-gated ionic currents, such as $g_{\mathrm{K}, \mathrm{L}}$, that mark utricle hair cell maturity (Rusch et al., 1998) were observed at P0+10DIV (see also Gaboyard et al., 2005), it is unlikely that only intrinsic factors that would affect $I_{\mathrm{Na}}$ expression in vivo are lost in culture. A study recently published by our group strongly supports the idea of a control of $I_{\mathrm{Na}}$ expression by the ongoing innervation. We studied the expression $I_{\mathrm{Na}}$ in utricle hair cells from rats developed under enhanced gravity (Brugeaud et al., 2006). This experimental condition was reported to delay synaptogenesis (specifically the synaptic stabilization) by $4 \mathrm{~d}$ (Gaboyard et al., 2003; Bouet et al., 2004). In this model, $I_{\mathrm{Na}}$ downregulation was also delayed by $4 \mathrm{~d}$, whereas its biophysical properties were unaffected. This additional observation confirms the relationships between the innervation and the downregulation of $I_{\mathrm{Na}}$ and strengthens the idea 
of a control of the developmental expression $I_{\mathrm{Na}}$ by the innervation. In type II hair cells that develop and become innervated earlier than type I, it can be assumed that the downregulation of $I_{\mathrm{Na}}$ would occur earlier. This remains to be demonstrated. We can question whether the influence of the nerve fibers on the hair cell electrical phenotype results from the cell-to-cell contact of the nerve terminals with the hair cell membrane or whether it results from synaptic stabilization. Because at birth, when immature synaptic contacts are identifiable, most hair cells express $I_{\mathrm{Na}}$, the latter hypothesis appears more likely.

\section{Recovery of excitability in adult utricle hair cells after nerve terminal impairment in vivo}

The use of the gelfoam method to produce selective excitotoxic impairment of the nerve terminals is, to our knowledge, unique in the vestibule. Such a technical approach appears appropriate because we observed morphological damage similar to that reported after intra-labyrinthine application of glutamatergic agonists in mammals (Liu 1999; Shimogori and Yamashita, 2004). The transient occurrence of the selective damages and the underlying vestibular disorders confirms the efficiency of the method. The glutamatergic nature of the excitotoxic impairment was attested (1) by the selective swelling of afferent terminals bearing glutamate receptors conversely to the efferents and (2) by the neuroprotective effect of DNQX. This result is in agreement with our recent demonstration that the non-NMDA receptors play a major role at the primary vestibular synapse (Bonsacquet et al., 2006). The fact that the biophysical and pharmacological properties of $I_{\mathrm{Na}}$, in the kainate-treated utricles, are similar to those in neonate utricles suggests that the same sodium channel is reexpressed after excitotoxicity. This is supported by the reexpression of the $\mathrm{Na}_{\mathrm{v}} 1.2$ subunit. The dependency between hair cell excitability and the state of the nerve terminals was confirmed by the downregulation of $I_{\mathrm{Na}}$ because the nerve fibers recontacted the hair cells 1 week after the kainate application. The lack of reafferentation after kainate treatment in $20 \%$ of the tested rats may result from the toxic effect of kainate previously reported on auditory ganglion neurons (Juiz et al., 1989). The persistence of $I_{\mathrm{Na}}$ in a small population of adult hair cells under control conditions remains unexplained. It may result from hair cells undergoing reafferentation after hair cell regeneration, which has been reported to occur in adult mammal utricles (Warchol et al., 1993). However, the small degree of turnover would not account for the estimated proportion of persistent $I_{\mathrm{Na}}$. Another possibility is that the persistent $I_{\mathrm{Na}}$ might involve the $\mathrm{Na}_{\mathrm{v}} 1.5$ subunit, the expression of which is restricted to striolar hair cells and is not developmentally regulated (Wooltorton et al., 2005). Based on the observations reported here, we suggest that the recovery of hair cell excitability results from the release of cellular mechanisms that normally prevent membrane expression of $I_{\mathrm{Na}}$ after synaptogenesis is complete.

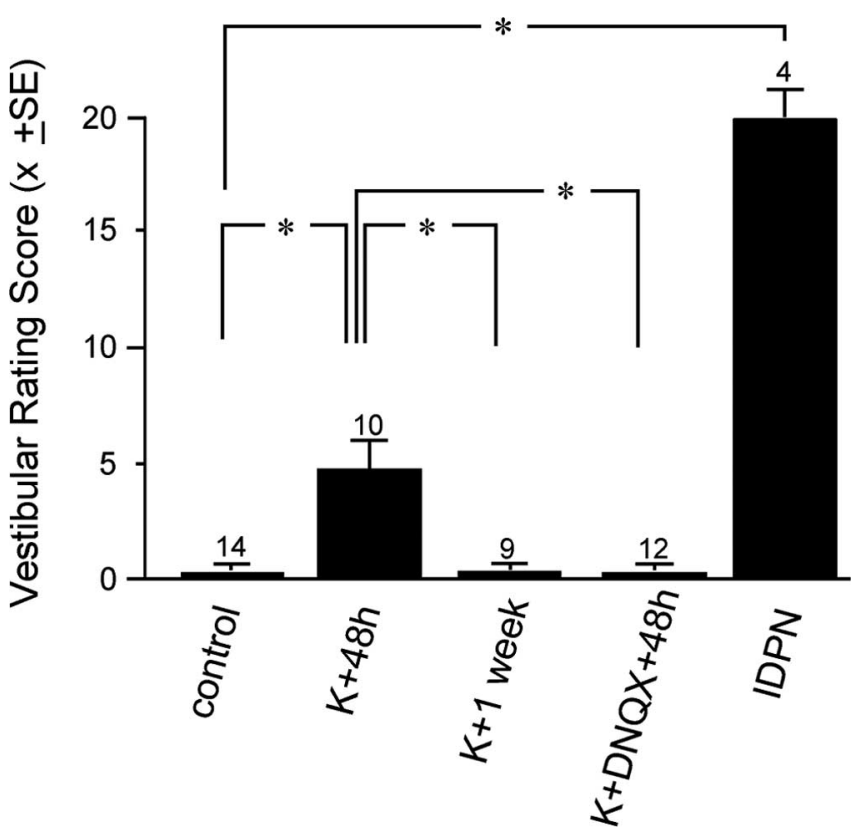

Figure 5. Behavioral consequences of transient nerve terminal impairment. Rating scores for vestibular dysfunction from a behavioral test battery are shown. Rats were assessed at $2 \mathrm{~d}$ $(\mathrm{K}+48 \mathrm{~h})$ or $7 \mathrm{~d}(\mathrm{~K}+1$ week) after kainate application or $2 \mathrm{~d}$ after kainite plus DNQX $(K+D N Q X+48 h)$ application. The kainate-induced vestibular dysfunctions were transient and prevented by DNQX. Data from a positive control group of animals treated with a dose of $3,3^{\prime}$-iminodipropionitrile (IDPN) that induces a complete loss of hair cells are shown. The total number of cells studied at each stage of development is shown above each bar. 


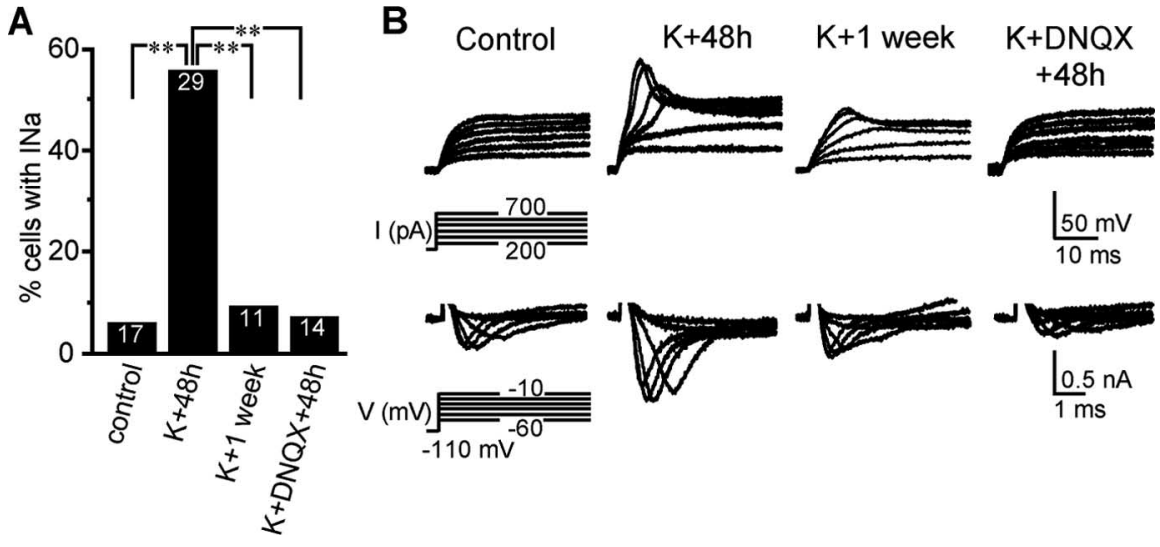

Figure 6. Transient recovery of excitability in adult utricle hair cells after nerve terminal impairment. $A$, Diagram showing the percentage of utricle hair cells expressing $I_{\mathrm{Na}}$ in given conditions. The total number of recorded cells is shown at the top of each bar. ${ }^{* *} p<0.01$. B , Representative voltage responses (top traces) for the given protocol, with the underlying whole-cell currents (bottom traces). Capacitive transients have been truncated for clarity. All traces are single traces. A high-density $I_{\mathrm{Na}}$ supporting a sodium-based AP was observed only $48 \mathrm{~h}$ after kainate application $(K+48 \mathrm{~h})$. Voltage and current traces shown under neuroprotection $(\mathrm{K}+\mathrm{DNQX}+48 \mathrm{~h})$ and recovery $\left(\mathrm{K}+1\right.$ week) conditions are those of the only cells expressing $I_{\mathrm{Na}}$ in these two sets of conditions (mean $C_{m}$ of 3.3 and $3.9 \mathrm{pF}$, respectively).
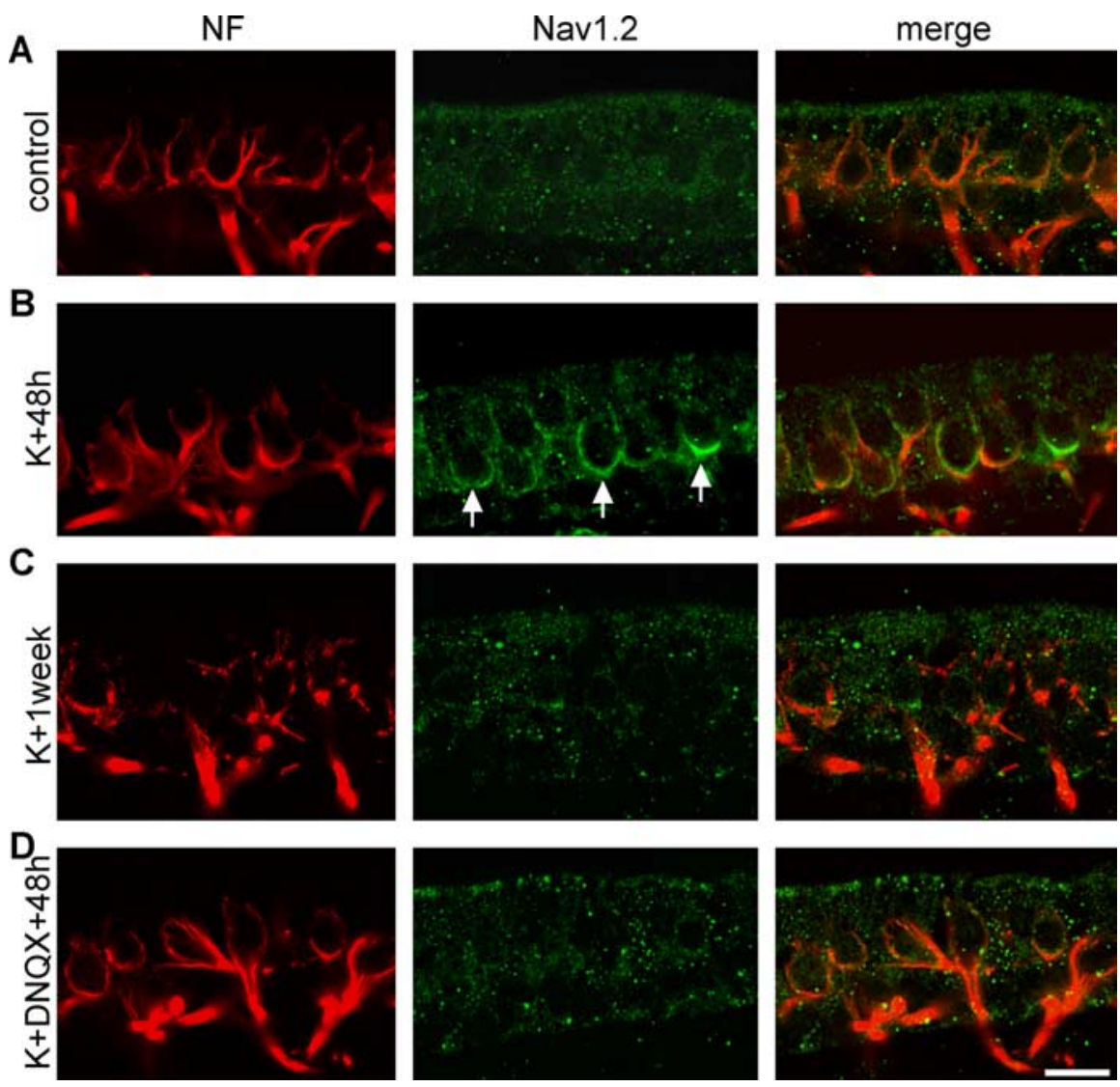

Figure 7. Transient recovery of $\mathrm{Na}_{v} 1.2$ expression in adult utricle hair cells after nerve terminal impairment. Immunolocalization of neurofilament-N52 (NF; red) and $\mathrm{Na}_{v} 1.2 \alpha$ (green) subunits in adult rat utricles in given conditions is shown. $\boldsymbol{A}, \mathrm{Na}_{v} 1.2$ labeling is not detected in utricle hair cells or in supporting cells in control. $\boldsymbol{B}$, Forty-eight hours after kainate application, a strong $\mathrm{Na}_{\mathrm{v}} 1.2$ immunoreactivity was observed at the basal hair cell membrane (arrows). C, D, Na 1.2 immunoreactivity does not persist 1 week after kainate application (C) and is absent in $\mathrm{K}+\mathrm{DNQX}+48 \mathrm{~h}$ experimental conditions (D). Scale bar (in D), $10 \mu \mathrm{m}$.

\section{Plasticity in voltage-gated sodium channel expression} The present results strongly suggest that in utricular hair cells, the expression of the sodium current is a dynamic process. Such plasticity has been widely studied in spinal sensory neurons in which the expression of various sodium channels isoforms is regulated during development (Roy and Narahashi, 1992) or after nerve injury (Waxman et al., 1994; Black et al., 1999; Dib-Hajj et al., 1999; Kim et al., 2001). Using immunocytochemistry, we demonstrated that the $\mathrm{Na}_{\mathrm{v}} 1.2$ subunit is downregulated in hair cells during synaptogenesis (Chabbert et al., 2003). This result is consistent with other observations in mammalian retinal ganglion cell axons in which $\mathrm{Na}_{\mathrm{v}} 1.2$, first clustered at immature nodes of Ranvier, is downregulated and replaced by $\mathrm{Na}_{\mathrm{v}} 1.6$ as myelination proceeds. In contrast, $\mathrm{Na}_{\mathrm{v}} 1.2$ continues to be expressed throughout adult axons of retinal ganglion cells in shiverer mice (Boiko et al., 2001), which lack compact myelin, and also on adult photoreceptors in the human retina (Kawai et al., 2005), which lacks myelin. In the present study, we showed that $\mathrm{Na}_{\mathrm{v}} 1.2$ membrane expression is upregulated after nerve terminal impairments. Such a phenomenon has also been reported to occur in rat hippocampal neurons after kainateinduced seizure (Gastaldi et al., 1997). Together, these observations suggest that $\mathrm{Na}_{\mathrm{v}} 1.2$ may be specifically involved in a wide variety of developmental processes in sensory neurons. However, because various $\mathrm{Na}_{\mathrm{v}}$ isoforms are expressed in utricular hair cells (Chabbert et al., 2003; Mechaly et al., 2005), it would be of interest to test whether other $\mathrm{Na}_{\mathrm{v}}$ isoforms are also regulated after nerve terminal impairment. Several neurotrophic factors have been shown to regulate sodium channel transcription in spinal sensory neurons. For example, exposure to nerve growth factor and/or glial cell neurotrophic factor differentially promotes the expression of sodium currents (Fjell et al., 1999; Leffler et al., 2002). In addition, in PC12 cells expressing trkB receptor, BDNF increases type II sodium channel mRNA expression (Fanger et al., 1995). We previously reported that an activity-dependent secretion of BDNF occurs in the rat utricle during synaptogenesis (Chabbert et al., 2003). Therefore, it would certainly be worthwhile studying whether this is reactivated after nerve terminal impairment and to what extent it controls the expression of the voltage-gated sodium current.

\section{Physiological relevance}

and perspectives

Ischemic damage to the inner ear constitutes a major cause of hearing loss and vertigo in man (Puel, 1995). It has now been clearly established that such damage is mediated by the massive release of glutamate by hair cells, resulting in excitotoxic damage to auditory (Puel et al., 1994, 1995; 
Hakuba et al., 2003) and vestibular (Liu, 1999; Shimogori and Yamashita, 2004) synapses. The transient nature of such damage, which is well documented in the mammalian cochlea, indicates that local repair processes may occur under specific conditions (Puel et al., 1995). We provide here the first evidence that such processes also exist in the vestibular endorgans and that they occur through the modulation of hair cell sodium excitability. The involvement of the efferents in that repair process remains to be elucidated. Additional experiments using selective bloc of the efferent synaptic transmission would allow to asses their involvement in the restoration of the vestibular function after excitotoxicity. The data presented here are thus of particular importance because they help to understand how synaptic contacts between hair cells and their cognate afferents are formed and repaired in mammalian vestibular organs. Studies of this type are a prerequisite for the development of strategies to protect the vestibular synapse against local ischemia and repairing damage caused by this condition.

\section{References}

Black JA, Cummins TR, Plumpton C, Chen Y, Clare J, Waxman SG (1999) Upregulation of a previously silent sodium channel in axotomized DRG neurons. J Neurophysiol 82:2776-2785.

Boadas-Vaello P, Riera J, Llorens J (2005) Behavioral and pathological effects in the rat define two groups of neurotoxic nitriles. Toxicol Sci 88:456-466.

Boiko T, Rasband MN, Levinson SR, Caldwell JH, Mandel KG, Trimmer JS, Matthews G (2001) Compact myelin dictates the targeting of two sodium channel isoforms in the same axon. Neuron 30:91-104.

Bonsacquet J, Brugeaud A, Compan V, Desmadryl G, Chabbert C (2006) AMPA type glutamate receptor mediates neurotransmission at turtle vestibular calyx synapse. J Physiol (Lond) 576:63-71.

Bouet V, Wubbels RJ, Jong HAA, Gramsbergen A (2004) Behavioural consequences of hypergravity in developing rats. Dev Brain Res 153:69-78.

Brugeaud A, Gaboyard-Niay S, Puel JL, Chabbert C (2006) Hypergravity affects the developmental expression of voltage-gated sodium current in utricular hair cells. NeuroReport 17:1697-1701.

Chabbert C, Mechaly I, Sieso V, Giraud P, Brugeaud A, Lehouelleur J, Couraud F, Valmier J, Sans A (2003) Voltage-gated $\mathrm{Na}^{+}$channels activation regulates both action potential and BDNF release in rat utricular hair cells during a restricted period of development. J Physiol (Lond) 553:113-123.

Chen JW, Eatock RA (2000) Major potassium conductance in type I hair cells from rat semicircular canals: characterization and modulation by nitric oxide. J Neurophysiol 84:139-151.

Correia MJ, Lang DG (1990) An electrophysiological comparison of solitary type I and type II vestibular hair cells. Neurosci Lett 116:106-111.

Curthoys IS (1982) Postnatal developmental changes in the response of rat primary horizontal semicircular canal neurons to sinusoidal angular accelerations. Exp Brain Res 47:295-300.

Dechesne CJ, Mbiene JP, Sans A (1986) Postnatal development of vestibular receptor surfaces in the rat. Acta Otolaryngol 101:11-18.

Desmadryl G, Sans A (1990) Afferent innervation patterns in crista ampullaris of the mouse during ontogenesis. Brain Res Dev Brain Res 52:183-189.

Desmadryl G, Raymond J, Sans A (1986) In vitro electrophysiological study of spontaneous activity in neonate mouse vestibular ganglion neurons during development. Brain Res 390:133-136.

Dib-Hajj SD, Fjell J, Cummins TR, Zheng Z, Fried K, LaMotte R, Black JA, Waxman SG (1999) Plasticity of sodium channel expression in DRG neurons in the chronic constriction injury model of neuropathic pain. Pain 83:591-600.

Eatock RA, Hurley KM (2003) Functional development of hair cells. Curr Top Dev Biol 57:389-448.

Ernfors P, Van De Water T, Loring J, Jaenisch R (1995) Complementary roles of BDNF and NT-3 in vestibular and auditory development. Neuron 14:1153-1164.

Evans MG, Fuchs PA (1987) Tetrodotoxin-sensitive, voltage-dependent so- dium currents in hair cells from the alligator cochlea. Biophys J 52:649-652.

Fanger GR, Jones JR, Maue RA (1995) Differential expression of neuronal sodium expression by endogenous and exogenous tyrosine receptors expressed in pheochromocytoma cells. J Neurosci 15:202-213.

Fjell J, Cummins TR, Dib-Hajj SD, Fried K, Black JA, Waxman SG (1999) Differential role of GDNF and NGF in the maintenance of two TTXresistant sodium channels in adult DRG neurons. Mol Brain Res 67:267-282.

Gaboyard S, Sans A, Lehouelleur J (2003) Differential impact of hypergravity on maturing innervation in vestibular epithelia during rat development. Dev Brain Res 143:15-23.

Gaboyard S, Chabbert C, Travo C, Bancel F, Lehouelleur J, Sans A (2005) Three dimensional culture of newborn rat utricle with extracellular matrix: a new functional in vitro model. Neuroscience 133:253-265.

Gastaldi M, Bartolomei F Massacrier A, Planells R, Robaglia-Schlupp A, Cau $P$ (1997) Increase in mRNAs encoding neonatal II and III sodium channel a-isoforms during kainite-induced seizures in adult rat hippocampus. Mol. Brain Res 44:179-190.

Geleoc G, Risner JR, Holt JR (2004) Developmental acquisition of voltagedependent conductances and sensory signaling in hair cells of the embryonic mouse inner ear. J Neurosci 24:11148-11159.

Guitton MJ, Caston J, Ruel J, Johnson RM, Pujol R, Puel JL (2003) Salicylate induces tinnitus through activation of cochlear NMDA receptors. J Neurosci 23:3944-3952.

Hakuba N, Matsubara A, Hyodo J, Taniguchi M, Maetani T, Shimizu Y, Tsujiuchi Y, Shudou M, Gyo K (2003) AMPA/kainate-type glutamate receptor antagonist reduces progressive inner hair cell loss after transient cochlear ischemia. Brain Res 979:194-202.

Juiz JM, Rueda J, Merchán JA, Sala ML (1989) The effects of kainic acid on the cochlear ganglion of the rat. Hear Res 40:65-74.

Kawai F, Horiguchi M, Susuki H, Miyachi E (2001) $\mathrm{Na}^{+}$action potentials in human photoreceptors. Neuron 30:451-458.

Kawai F, Horiguchi M, Ichinose H, Ohkuma M, Isobe R, Miyachi E (2005) Suppression by an $\mathrm{h}$ current of spontaneous $\mathrm{Na}^{+}$action potentials in human cone and rode photoreceptors. Invest Ophthalmol Vis Sci 46:390-397.

Kim CH, Oh Y, Chung JM, Chung K (2001) The changes in expression of three subtypes of TTX sensitive sodium channels in sensory neurons after spinal nerve ligation. Mol Brain Res 95:153-161.

Kros CJ, Ruppersberg P, Rusch A (1998) Expression of a potassium current in inner hair cells during development of hearing in mice. Nature 394:281-284.

Leffler A, Cummins TR, Dib-hajj SD, Hormuzdiar WN, Black JA, Waxman SG (2002) GDNF and NGF reverse changes in repriming TTX-sensitive $\mathrm{Na}^{+}$currents following axotomy of dorsal root ganglion neurons. J Neurophysiol 88:650-658.

Liu TC (1999) The effects of kainic acid on the vestibular ganglion cells. Neurosci Res Commun 24:81-88.

Llorens J, Demêmes D, Sans A (1993) The behavioral syndrome caused by $3,3^{\prime}$-iminodipropionitrile and related nitriles in the rat is associated with degeneration of the vestibular sensory hair cells. Toxicol Appl Pharmacol 123:199-210.

Mechaly I, Scamps F, Chabbert C, Couraud F, Sans A, Valmier J (2005) Molecular diversity of voltage-gated sodium channels alpha subunits expressed in neuronal and non-neuronal excitable cells. Neuroscience 130:389-396.

Pan ZH, Hu HJ (2000) Voltage-dependent $\mathrm{Na}^{+}$currents in mammalian retinal cone bipolar cells. J Neurophysiol 84:2564-2571.

Puel JL (1995) Chemical synaptic transmission in the cochlea. Prog Neurobiol 47:449-476.

Puel JL, Pujol R, Tribillac F, Ladrech S, Eybalin M (1994) Excitatory amino acid antagonists protect cochlear auditory neurons from excitotoxicity. J Comp Neurol 341:241-256.

Puel JL, Saffiedine S, Gervais d'Aldin, Eybalin M, Pujol R (1995) Synaptic regeneration and functional recovery after excitotoxic injury in the guinea pig cochlea. C R Acad Sci III 318:67-75.

Roy ML, Narahashi T (1992) Differential properties of tetrodotoxinsensitive and tetrodotoxin-resistant sodium channels in rat dorsal root ganglion neurons. J Neurosci 12:2104-2111. 
Rusch A, Lysakowski A, Eatock RA (1998) Postnatal development of type I and type II hair cells in the mouse utricle: acquisition of voltage-gated conductances and differentiated morphology. J Neurosci 18:7487-7501.

Schimmang T, Minichiello L, Vazquez E, San Jose I, Giraldez F, Klein R, Represa J (1995) Developing inner ear sensory neurons require TrkB and TrkC receptors for innervation of their peripheral targets. Development 121:3381-3391.

Seoane A, Dememes D, Llorens J (2001) Pathology of the rat vestibular sensory epithelia during subchronic 3,3'-iminodipropionitrile exposure: hair cells may not be the primary target of toxicity. Acta Neuropathol 102:339-348.

Shimogori H, Yamashita H (2004) Peripheral vestibular disorder induced by (土)- $\alpha$-amino-3-hydroxy-5-methyl-isoxazole-4-propionic acid (AMPA). Neurosci Lett 371:69-72.

Warchol ME, Lambert PR, Goldstein BJ, Forge A, Corwin JT (1993) Regenerative proliferation in inner ear sensory epithelia from adult guinea pigs and humans. Science 259:1619-1622.

Waxman SG, Kocsis JD, Black JA (1994) Type III sodium channel mRNA is expressed in embryonic but not in adult spinal sensory neurons, and is reexpressed following axotomy. J Neurophysiol 72:466-470.

Wooltorton J, Gaboyard S, Hurley KM, Price SD, Garcia JL, Zhong M, Lysakowski A, Eatock RA (2007) Developmental changes in two voltage-dependent sodium currents in utricular hair cells. J Neurophysiol 97:1684-1704 